\title{
$=$ \\ The Effect of Total Quality Standards on Developing Textile Arts-Based on Creativity of Najran University Students ${ }^{*}$
}

\author{
Dr. Wafaa Mohamed Ibrahem Elbana \\ Assistant Professor of Textiles at the College of Education - Najran University- KSA \\ Email: wmalbana@nu.edu.sa
}

Dr. Shreen Hassan Mahmoud Hegazy

Principle Investigator (PI) - Associate Professor of Clothes and Textile, Faculty of

Education-Najran University- KSA

Email: shhegazy@nu.edu.sa

\begin{abstract}
There is no doubt that the interest in the quality of production started in tandem with the beginning of the human learning of the letter, and this interest has increased with time. The increase in civil and its complexities, The multiplicity of competition between individuals, companies, and countries led to precise requirements for product quality, And this accuracy continues to evolve with the development of measuring devices tremendously due to the need for the purposes to be achieved according to the desires of the consumer. The current research aims to identify the extent of opening new areas of work through textile artifacts of an aesthetic and utilitarian nature and the use of total quality in their production to obtain the highest standards of quality and consumer satisfaction. The study relies on the descriptive and analytical approach in addition to the applied study due to the nature of the research that uses the description and analysis of designs. The study relied on using the tissue composition $1 / 1$ to produce textile artifacts of an aesthetic nature and have multiple utility uses provided that this is done within the framework of comprehensive quality standards to achieve the highest possible Of the specifications that distinguish the product and satisfy the consumer. The study sample consists of a group of female students at Najran University (12 female students), and the study tools include a measure of professional skills (prepared by the researchers), textile products produced according to comprehensive quality standards (prepared by the researchers), and the data are processed statistically using the Statistical Package for Social Sciences program. SPSS by calculating the averages, standard deviations and correlation coefficients to identify the significance of the differences between the averages of the grade scores in the post and pre-measurement.
\end{abstract}

Keywords: Quality, Total Quality Management, Innovation and Creativity, Textile Arts.

\footnotetext{
* Research supported by the Deanship of Scientific Research at Najran University Research Code: NU/SHED/17/216
} 


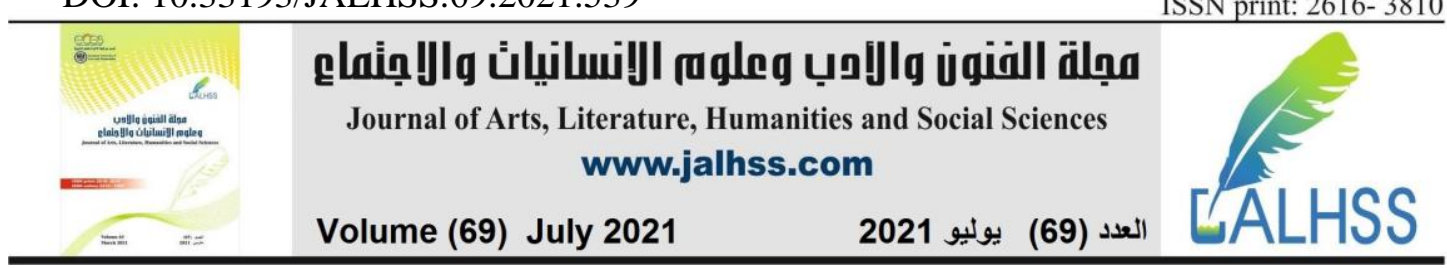

\section{Introduction}

Awareness of the importance of quality has increased, as, it is one of the most important topics that has been and continues to be extremely important in any institution, whether productive or service. Quality has become a source of attention for any organization and its concern, in order to achieve a competitive advantage that enables it to face the challenges of the time and consumer satisfaction. (Muhammad, 2000)

The concept of total quality is considered a strategic goal for all institutions that seek to improve the level of their performance, and ensure the quality of their outputs. Because of the availability of its standards on the ground, giving the institution a clear work mechanism for workers and beneficiaries alike (Mabrouk, 2007).

In solidarity with this trend, the researcher uses several methods and techniques in the current research with the aim of achieving continuous improvement in the level of product quality, in order to achieve total customer satisfaction. This by setting standards for continuous improvement in all processes and stages, in order to constantly adapt to the changes that occur in fashion and consumer taste.

In order achieve the vision (2030), ( Uywn, 2000) which is strongly aims to enhance the potentials of the promising and diversifying economic sectors in the Kingdom of Saudi Arabia, and generating job opportunities, and from this standpoint, the issue of research and direction towards hand work has been considered. This is in pursuit of applying it on all levels, to be an ambitious country with its production and achievements. The sustainability of success can only be by sustaining the elements of this success, and investing human resources in hand work and achieving the desired goal for the Kingdom by opening new professional fields and terminating unemployment

As (Saqr, 2003) stated that handwork is the next future, as it is specialized by free expression and individual performance, which results in a variety of aesthetics and artistic values. The textile arts considered distinctive arts of these handicrafts. (Mahmoud, 2003) agreed with him that besides this, those of the textile arts produce aesthetics and values that are subject for formulations of artistic formation and intellectual dialogue, which produce special philosophies for each individual in which the direction of the artist appears.

And, since the handicrafts in the Kingdom of Saudi Arabia limited in the handmade textile industry as a traditional craft with a tendency to disappear as a local artistic product, and to replace it with non-local products, and not to give it its place as one of the arts on the artistic scene (Al-Saleh, 2010). Thus, textile art is considered an applied art that has its artistic and aesthetic values due to the function it performs in an individual's life, as textile designs have always been a mirror of its present, civilization and artistic trends (Abu Al-Anin, 2000).

In view of the human resources which considered one of the most important elements of the economic and social development process, human resources development is a series of procedures and basis aimed to organize individuals to obtain the maximum possible benefits from human competencies, and to extract their best energies, also, is 


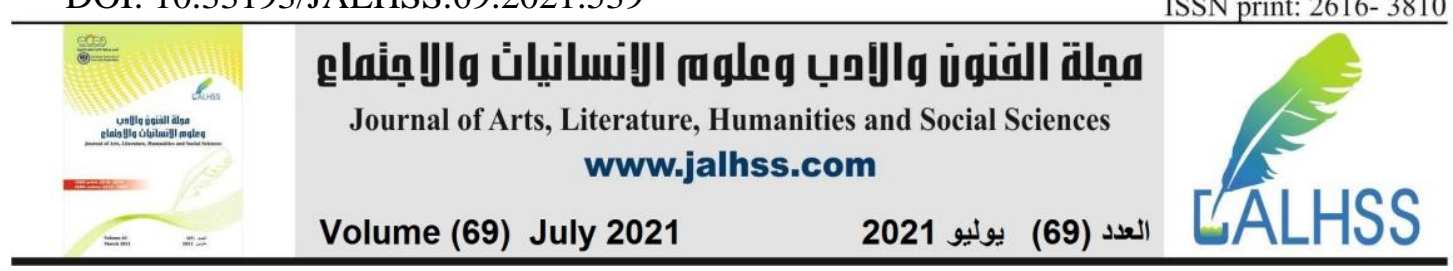

an entry point to achieve the comprehensive development process, and from this, emerged an urgent need to the importance of training for these human resources, through the production of handicrafts, and in this context we find many researchers who addressed the importance of training on this to identify the needs that help in advancing human development, including a study (Saleh, 2011).

Both handwork and development are closely related to the development of human forces with the aim of achieving human development, and thus society in all social, economic and cultural fields. The training consider among the solutions proposed to solve modern civilizational problems, training is considered an investment in human capital to enable the individual to play the role which is assigned to him within the framework of the modern environment, and to help him adapt to the conditions of work. (Alex, 2004).

In view of these studies, we note that they agreed to define the importance of handicrafts in establishing small projects

From the foregoing, it is clear that the importance of the research which highlights the importance of applying the comprehensive quality system, as the most prominent fields that contribute to that development of handcarts in general and textile works in particular, and this was indicated by a study (Taha and Alshemy, 2020; Hassan, 2010).

Unemployment is a prominent phenomenon in the Arab world, and it is difficult to ignore it. The vast majority of the unemployed are graduates of universities and institutes, and this means wasting energies and human resources that have been invested in the educational process without resulting in a return. There is no doubt that small projects play an important and effective role in overcoming these the problem. This is confirmed by the study of (Levi Strauss Company, 2006) that small projects provide job opportunities for graduates, and contribute to facing the problem of unemployment, as well as, raising the standard of living and increasing economic income. Meaning that small projects responsible for achieving optimal exploitation of the idle human capacities, depending on the characteristics of these projects, making it more effective in absorbing the surplus of work than what large industries can achieve The study Problem

The research problem is summarized at the weak competitive advantage of textile products, which negatively affects the opening of fields for small projects. Therefore, the problem of study is the following main question:

What is the effect of using total quality standards on developing creativity and innovation skills related to textile arts for students of Najran University?

The main question is divided into some sub-questions:

- What is the level of vocational skills related to textile arts among students of the, College of Education, University of Najran, study sample?

- Are there statistically significant differences at the level of vocational skills associated with textile arts between the experimental group and the control group before applying the total quality standards? 


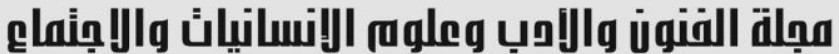 \\ Journal of Arts, Literature, Humanities and Social Sciences www.jalhss.com}

Volume (69) July 2021

2021 يوليو

(69) (6لعدد)

- Are there statistically significant differences at the level of vocational skills associated with textile arts between the experimental group and the control group after applying the total quality standards?

- Are there statistically significant differences between the pre and post measurement of the experimental group at the level of vocational skills related to textile arts?

- Is there a relationship between product quality, and the opening of new fields of work in textile arts?

\section{The study Objectives}

1- Introduce new textile methods to develop some professional skills related to textile arts for Najran University students;

2-Try to draw an attention to the importance of quality in overcoming productivity problems and raising competitiveness;

3- Provide some suggestions and recommendations in regards the subject of the study in light of the results of the study, and;

4- Invest the energy and the skills of the students of College of Education, University of Najran, and convert them to productive human resources.

\section{The importance of studying}

The importance of induction is determined in the following points:

1. The development of textile arts is based on total quality management in its broad and comprehensive concept;

2. Individuals are an investment, if its best development can achieve the goals of the organization and increase its productivity;

3. The quality of human resources and the development of its innovative skill provides the institution with a competitive advantage by which it can keep up with the labor market

4. Textile works are an important pillar for developing small projects, and opening a new field in the labor market.

\section{The study sample}

Twelve female students were selected from the Home Economics Program at Najran University

\section{study Methodology}

The current research uses two descriptive method approaches, related to identifying theoretical skills and knowledge, associated with the design of a professional program in textile arts. An experimental approach in relation to the research experiment, and measuring The effect of using total quality standards in developing some of the professional skills associated with the textile arts of female students.

\section{study confince}

The current study is determined by the sample used and they are (a sample of students of the College of Education - University of Najran), the measures and tools used, the statistical methods used, the results of the study. 


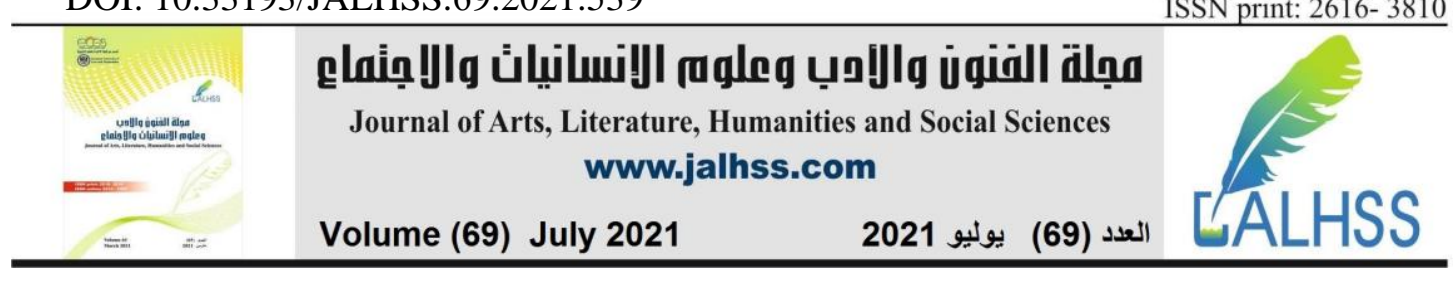

\section{Research tools and metrics}

- Note card to measure the effect of comprehensive quality standards on the skill of students

- The scale of theoretical information related to professional skills (prepared by the researcher)

\section{Research tools}

- Use simple textile structures

- Use simple hand looms

\section{Key words}

- Using wool yarn to implement some simple art forms

Quality concept: The concept of quality refers to the Latin word Qualitas Which means the nature of a person or thing and the degree of its validity, and it used to mean accuracy and proficiency in the past (Siddiq, 2012).

Total Quality Management: depends on quality control during production and manufacturing processes and is also known as a quality assurance system that ensures comprehensive quality control over all activities that enter and influence the production and service process, and it is also known as the method that ensures continuous improvement. (Ibn Aishi, 2018)

Total Quality Management Tools: These are methods of collecting and presenting data, and they are often columns for data that seem meaningless to the average person, but for trained people, reading a chart is much better than any traditional reports and tinny. Total quality management tools on quality control planning, perto planning, bone planning Fish, column, scatter, flow chart (Al-Adawi, 2005).

Continuous improvement: is to make every aspect of operations improved with purpose, i.e. knowing the changes that occur during work and what processes or projects need improvement, and making this philosophy the basis of product quality. (Metwally, 2002)

innovation and creativity: Linguistically innovation is synonymous with creativity, superiority, distinction, and the development of new methods and relationships in place of the old or recognized.

The art of weaving: It is an art that includes textile arts and techniques that are used to decorate textiles by dyeing and printing to add color and pattern, as well as machine hand embroidery, knitting and crochet, and the use of techniques such as (appliqué art), carpet works, and everything that falls under the concept of textile arts (Jenkins, 2003).

Textile composition: It is the structural unit of the woven, and it is defined as the lover's method between two sets of strings, one of which is longitudinal called the warp strings and the other is transverse and is called the weft (Al-Ghamdi, 2017).

Tabby Textile: The simplest combinations, as one repetition of it needs the least number of strings. They are two warp with two weft that interchange with each other .Thus, the warp strings are divided into single strands and even strings, each exchanging for each They appear and disappear from above or under the wefts. (Al-Ghamdi, 2017) (Yen- Pablo \& Brian, 2007) 


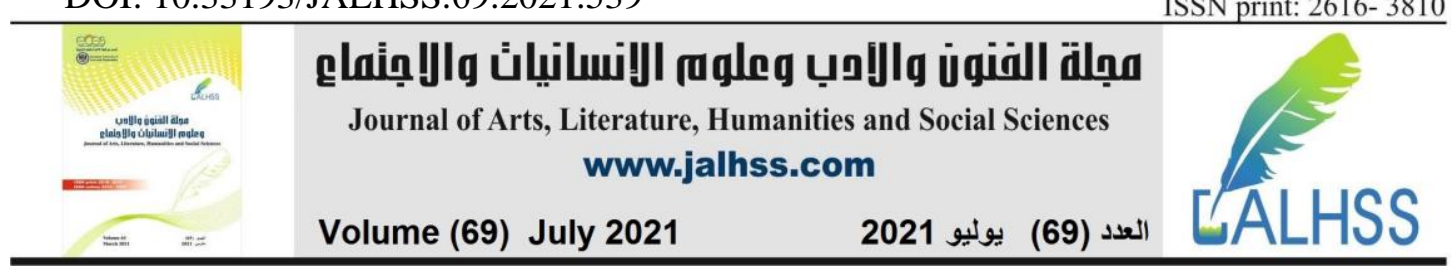

The program: A type of organized planning that consists of a set of effective linked elements, namely: objectives, content and teaching methods, and the evaluation used by the teacher or the learner, or the educational institution to bring about the desired changes (El-Yazal, Ibrahim, and Abdelqawy, 2014; Raj, Augello, \& Dent, 2007).

The training program: a renewed and continuous activity that starts with planning and ends with evaluation and aims to provide individuals with knowledge and skills in specific areas to improve their performance at work, or to change their attitudes and patterns of behavior for current or future performance to help achieve the goals of this work (Niyaz, 2008).

\section{Previous studies}

Studies related to the field of textile crafts:

Ibrahim, Al-Jamal, and Zalat (2020) conducted a study entitled "The effect of different Histopathology on some of the functional performance of upholstery fabrics." To the fact that the Histopathology of HNICOM are the best for evaluating the overall quality of all the performance properties of the cotton raw material.

The study (Yunus, 2014) confirmed that it is possible to take advantage of the technology of optical systems for the art of light and the multiple optical effects of the electrical circuit that depend on the color change of light in creating color changes on textile artifacts that enrich the hand textile in an unconventional direction, as it relied on employing color in unfamiliar dimensions. Through the use of colors in the form of moving lights.

As explained (Hassan, 2010), the value of the textile artwork varies in form and content between its proximity to the lack of direct and tangible utilitarianism to reach the height of pure aesthetic artistic creativity. This is achieved by multiple touches in the textile artwork through the use of many different textile effects and different textures that contribute to enriching the surface Woven fabric, using different materials and colors.

The importance of Yusuf (2012) in developing creativity skills among art students when studying the art of hand weaving, is shown by taking advantage of modern and contemporary trends and creating unconventional works for the purpose of continuous development and contributing to enriching textile works for the ability to compete in the labor market and create a fruitful harmony between different disciplines and contribute. Effective graduation of human cadres with available competence and that is from the multiplicity of one specialization.

The research (Adawiya, 2018) also aimed to prepare an educational program for Histopathology using multimedia that makes the student able to meet the needs of the labor market and fits the current era in terms of development, measuring the effectiveness of students 'achievement of the cognitive aspects contained in the simple Histopathology program using multimedia, so the researcher By studying simple tissue compositions and carrying out scientific references related to simple Histopathology, studying multimedia and its role in developing education,

Mahmoud (2013) showed the possibility of trying to overcome the problems facing junior students while carrying out weaving crafts, by using ready-made textile tapes executed using simple Histopathology, where ready-made tapes could replace strings, 


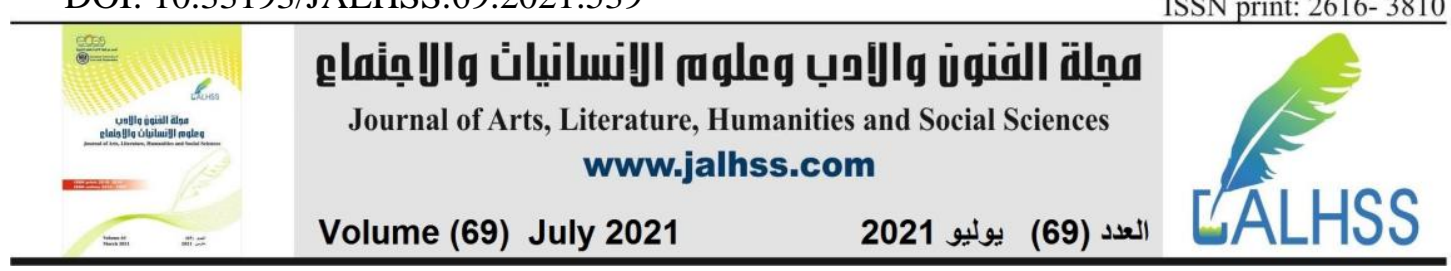

and the idea was highly accepted by students, which works For beginners, it supports experimentation opportunities to overcome the problems of weaving, and research is one of the modern approaches to teaching hand weaving in the educational field.

Al-Shimi (2012) confirmed, through this study, through this study, the investment of simple Histopathology, through which we can reach innovative solutions for the decorative design surface and then use these designs again to enrich Hand weaving pendants.

Naji (2013) also aimed at the possibility of identifying plain weave fabrics and their compositions and derivatives and chromatic influences on them as well as studying color through its connotations, symbols and data in fabric designs and how to manipulate designs of solid weave fabrics through these influences or variations of color and composition, and their configurations, with the threads of each of the dams. warp a weft.

\section{Studies related to quality management standards}

Al-Rabiah (2020) aimed at identifying the degree of application of comprehensive quality management standards in private universities in Jordan from the viewpoint of the faculty members in them. The research sample consisted of (150) faculty members chosen from three private universities by the simple random method. For this purpose, the researcher developed a questionnaire consisting of (59) items distributed into seven domains. To answer the research questions, the researcher used the arithmetic averages, the degree of application, and the rank for each paragraph and for each of its fields. The research found that the degree of application of TQM standards in private universities in Jordan was high, as well as the degree of application of TQM standards in private universities in the seven areas in descending order, information and analysis, utilization of human resources, assured quality in production, leadership, planning Strategic, Quality Results, Consumer Satisfaction. The results also reached an increase in the degree of application of total quality management standards in private universities in Jordan in the areas of leadership, information, analysis, strategic planning, utilization of human resources and quality assurance in production. The research recommended a set of recommendations. (Published summary)

Al-Amiri (2020) aims to find out the obstacles to the application of Total Quality Management and ways to improve them from the viewpoint of the students of the History Department at the College of Education for Girls at the University of Baghdad. The research community consisted of all the female students of the College of Education for Girls at the University of Baghdad, whose number is (3313) female students. The researcher randomly selected a basic sample of (95) female students from the history department. The questionnaire was used as a tool to achieve the goal of the research, as its validity was extracted by presenting it to a group of specialists in educational, psychological and history sciences, and its reliability based on the method of the Alpha Cronbach equation, as its reliability coefficient reached (95.6). In order to demonstrate the results of the research, statistical methods were adopted (the Cronbach alpha equation, Fischer equation, and the percentage weight), as the results showed the existence of a number of real obstacles in applying quality, which amounted to (19) items. The data also indicated the existence of false impediments in 


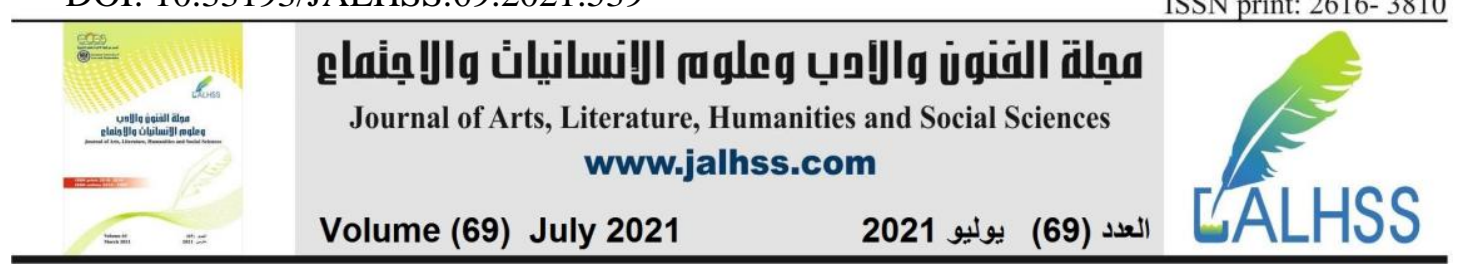

the application of quality, which were diagnosed from their point of view and considered unfulfilled in light of the approved standard (3.00), of which there are (16) paragraphs out of a total of (35) paragraphs, and in light of this the researcher put forward several conclusions, recommendations and suggestions. . (Published abstract)

Al-Adwani explained the importance of building a proposed training program to develop the concepts of comprehensive quality and its applications in education for quality specialists and school principals in the Republic of Yemen in light of sustainable development. To achieve the aim of the study, the descriptive survey approach was used, and the questionnaire tool was applied to the study sample consisting of (280) individual school principals and quality specialists in a number of governorates of the Republic of Yemen to determine their training needs and then build the proposed training program based on it and arbitrate the program with a number of experts and specialists. . The results of the study reached the approval of the study sample on all training needs to a large extent, and the building of a training program that develops the concepts of total quality and its applications in education for quality specialists and school principals in the Republic of Yemen in light of sustainable development. (Author's summary)

The study of Al-Adawi (2005) aimed to try to participate in finding new and simple mechanisms from practical reality that contribute to activating the role of a culture of reform, development and continuous improvement that represents the injustice and philosophy of total quality management, as well as making an actual tangible impact in achieving quality in the course outside the limits of the influence of material capabilities and capabilities Economic development in educational institutions because the development process is in constant and continuous need to diversify the means used to shed light on the appropriate technologies to achieve educational aimed

\section{Theoretical framework: \\ Training system: \\ First: Inputs:}

1- Human inputs represented by: the trainers and trainees (sample of the research is 12 female students).

2- Material inputs represented in:

Experiences, knowledge and information required to be provided to female students.

Training objectives.

Providing appropriate training programs for the training process

3- Financial inputs represented in the financial support available to complete the training process

\section{Second: Operations:}

The process of converting training inputs into outputs takes place in several stages:

Description and analysis of processes and procedures

- Identification of training needs .

Providing training equipment.

Implementation and supervision of the training program.

Follow-up and evaluation of the training activity 


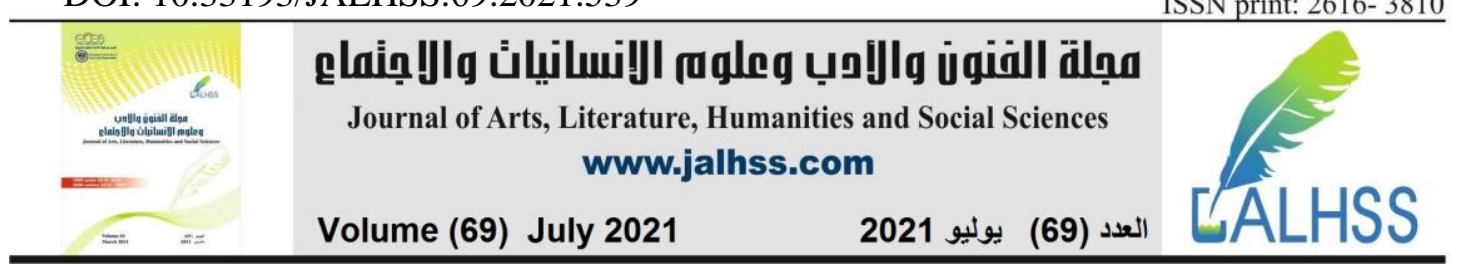

\section{Third: Outputs:}

The series of results and achievements that resulted from the previous operations of the training system, as it is the outcome of the interaction between the inputs and the processes and their integration together, and these outputs are represented in the cognitive, skill, behavioral, moral and material changes.

\section{Fourth: Feedback:}

It is a continuous follow-up procedure during the work stages to determine the extent to which the actual results match the targeted results, and to identify and treat deviations in order to ensure continuous improvement.

\section{Third: Outputs:}

The series of results and achievements that resulted from the previous operations of the training system, as it is the outcome of the interaction between the inputs and the processes and their integration together, and these outputs are represented in the cognitive, skill, behavioral, moral and material changes.

\section{Fourth: Feedback:}

It is a continuous follow-up procedure during the work stages to determine the extent to which the actual results match the targeted results, and to identify and treat deviations in order to ensure continuous improvement.

\section{Application framework:}

Preparing the training program: The process of building and preparing the training program has gone through many stages, as it is a system that requires a comprehensive plan that includes a number of interconnected sequential practical procedures, and these stages are:

1- Defining the training topic: The two researchers chose the topic of the program to advance human development, with the aim of providing the trainees with knowledge and skills to be a sound building unit through which a small project could be established, and the program included training on knowledge and skills:

$\square$ Knowledge and information included in the program:

- Knowledge of preparing small projects (definition of small projects - preparation of the feasibility study for small projects - methods of managing small projects - means of marketing for small projects)

- Knowledge of textile artifacts (including raw materials and auxiliary materials design characteristics - types of Histopathology- different types of looms - method of weaving the Histopathology tappy wave $1 / 1$ on the frame loom - methods of finishing the work) 


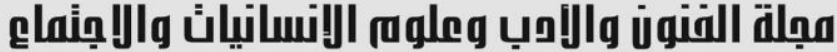

Journal of Arts, Literature, Humanities and Social Sciences www.jalhss.com

\begin{tabular}{|c|c|c|c|c|}
\hline Fudanck & Aoblilention Grammork & Gonla & 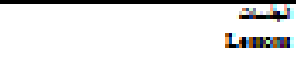 & 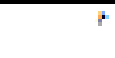 \\
\hline \multirow{8}{*}{$\frac{\mathrm{z}}{\frac{\mathrm{z}}{2}}$} & 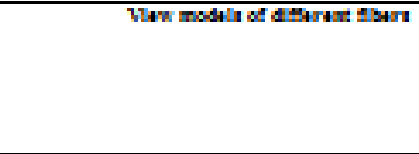 & 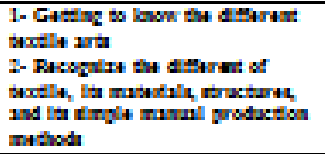 & 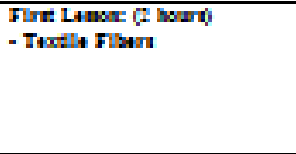 & \multirow{2}{*}{$\frac{2}{2}$} \\
\hline & 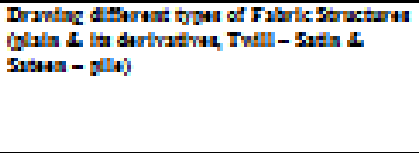 & 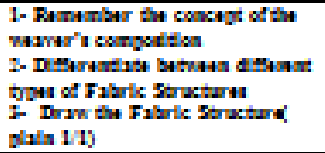 & 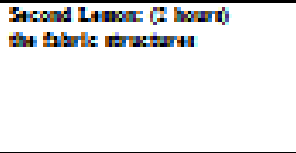 & \\
\hline & 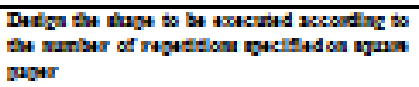 & $\begin{array}{l}\text { - Detiga and prodaction of bexell } \\
\text { groduct }\end{array}$ & 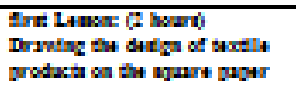 & \multirow{2}{*}{$\frac{\mathrm{g}}{\mathrm{z}}$} \\
\hline & 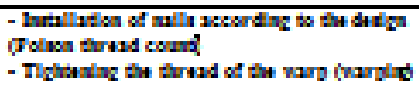 & 1- Warplag Frame losm & 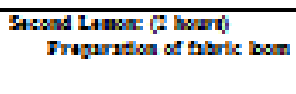 & \\
\hline & 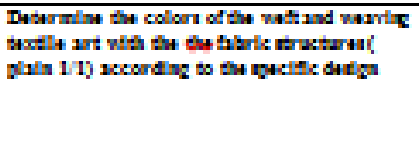 & 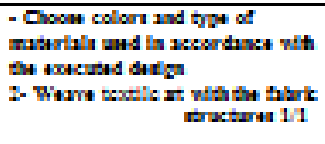 & 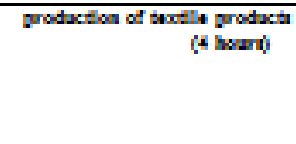 & $\frac{\xi}{E}$ \\
\hline & 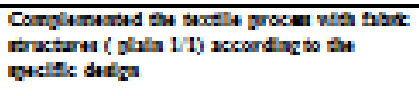 & 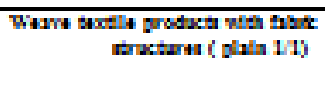 & 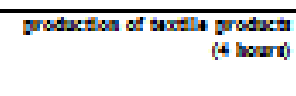 & 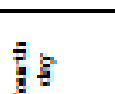 \\
\hline & 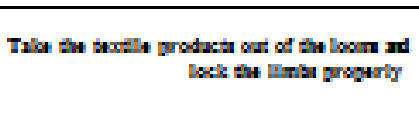 & 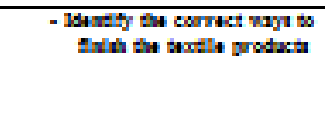 & $\begin{array}{l}\text { Finlth and andivg } \\
\text { nork (4 hodrit) }\end{array}$ & $\frac{2}{2}$ \\
\hline & 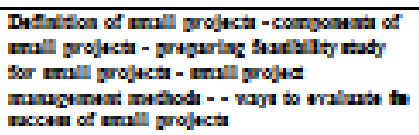 & 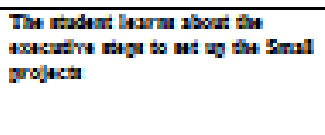 & $\begin{array}{l}\text { Srri Lamon: (2 Modrit) } \\
\text { Small groject }\end{array}$ & \multirow{2}{*}{$\stackrel{\frac{y}{2}}{\frac{y}{2}}$} \\
\hline & $\begin{array}{l}\text { Mtariativg muthodn and Mtwang } \\
\text { Sor andill groject }\end{array}$ & 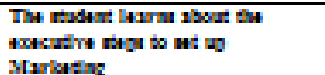 & $\begin{array}{l}\text { Stcond Lamox: (f modrit) } \\
\text { Mtarlativg }\end{array}$ & \\
\hline
\end{tabular}




\begin{tabular}{|c|c|}
\hline 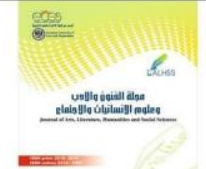 & 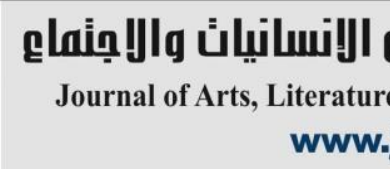 \\
\hline
\end{tabular}

Samples that were carried out by the students:

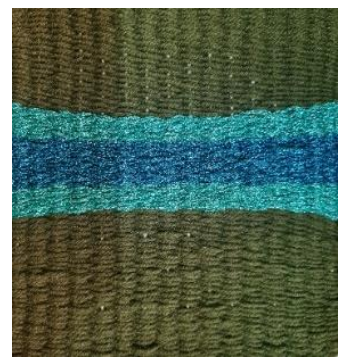

Sample (1)

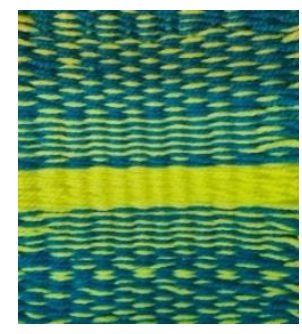

Sample (4)

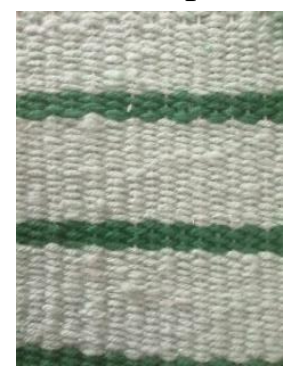

Sample (7)

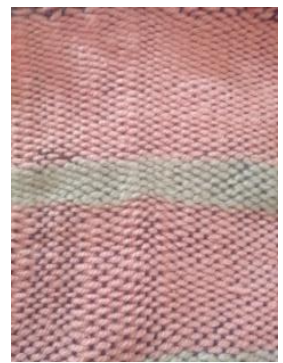

Sample (10)

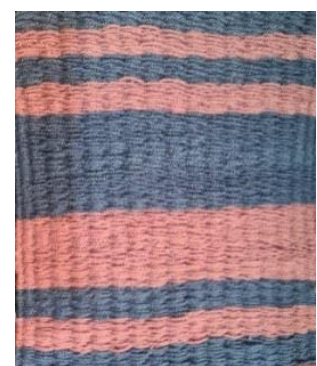

Sample (2)

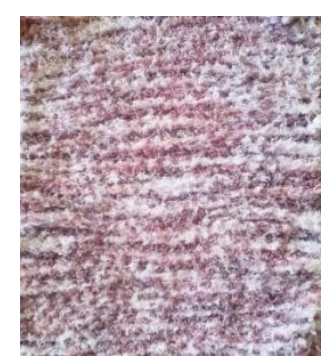

Sample (5)

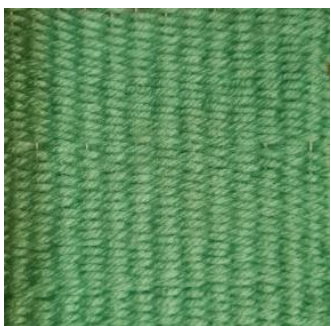

Sample (8)

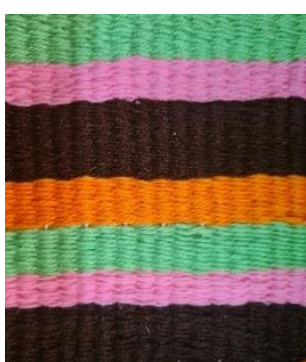

Sample (11)

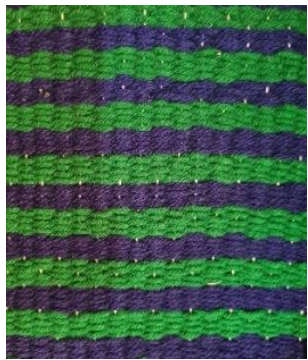

Sample (3)

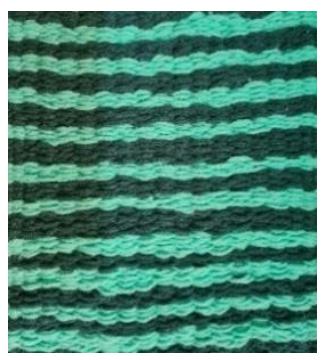

Sample (6)

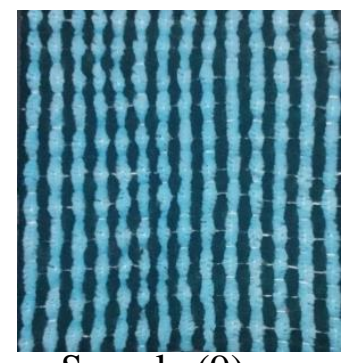

Sample (9)

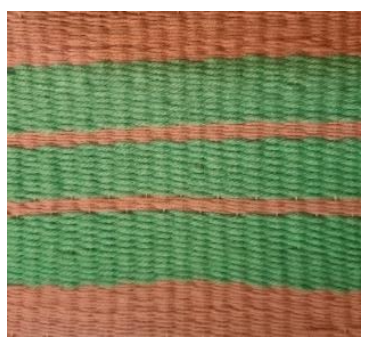

Sample (12) 


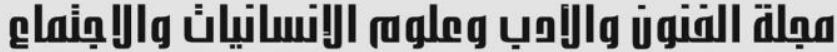 \\ Journal of Arts, Literature, Humanities and Social Sciences www.jalhss.com}

Volume (69) July 2021 يوليو 2021

(69) (6لعد (69)

\section{Descriptive of data}

Table (1): Description of test data, scale and note card

\begin{tabular}{|c|c|c|c|c|c|c|c|}
\hline & & & $\mathbf{N}$ & Min. & Max. & Mean & SD \\
\hline & & Pre & 12 & 2 & 6 & 4.00 & 1.13 \\
\hline ogecerse act & (1) & Post & 12 & 6 & 10 & 8.17 & 1.11 \\
\hline & & Pre & 12 & 4 & 6 & 5.00 & 0.85 \\
\hline & & Post & 12 & 8 & 10 & 8.83 & 0.83 \\
\hline & & Pre & 12 & 2 & 5 & 3.17 & 0.94 \\
\hline & & Post & 12 & 7 & 10 & 8.83 & 0.94 \\
\hline & & Pre & 12 & 4 & 6 & 4.83 & 0.72 \\
\hline & & Post & 12 & 8 & 10 & 9.17 & 0.58 \\
\hline & & Pre & 12 & 1 & 5 & 2.75 & 1.06 \\
\hline & & Post & 12 & 7 & 10 & 8.42 & 0.79 \\
\hline & Rating & Pre & 12 & 12 & 21 & 15.75 & 2.63 \\
\hline & scale & Post & 12 & 33 & 38 & 35.25 & 1.36 \\
\hline & & Error1 & 12 & 7 & 12 & 9.17 & 1.75 \\
\hline & Error & Error2 & 12 & 3 & 8 & 5.42 & 1.62 \\
\hline & & Error3 & 12 & 0 & 3 & 1.25 & 0.97 \\
\hline Note caru & & Time1 & 12 & 90 & 125 & 108.33 & 12.31 \\
\hline & Time & Time2 & 12 & 70 & 105 & 91.25 & 9.08 \\
\hline & & Time3 & 12 & 55 & 95 & 75.00 & 14.30 \\
\hline
\end{tabular}

Table (1) describes Objective achievement test data in the pre and post applications, Rating scale data for pre and post measurements, and Note card data during

\section{implementation}

\section{The first sub-question:}

\section{Statistical results of questions}

The question states, "What is the level of professional skills related to textile arts among female students, Department of Home Economics, Faculty of Education, University of Najran, sample of the study?"

In order to answer this question, the researcher calculated the percentage of the average pre-application scores for each skill and the scale as a whole, and the results came as shown in Table (2): 


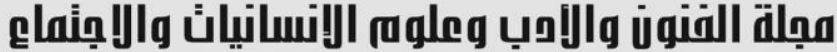 \\ Journal of Arts, Literature, Humanities and Social Sciences www.jalhss.com}

Volume (69) July 2021

يوليو 2021

(69) العدد (69)

Table (2): shows the percentage of the average pre-application scores for each skill and the scale as a whole

\begin{tabular}{|c|c|c|c|}
\hline Rating scale & Mean score & Max score & Percent (\%) \\
\hline Skill1 & 5.00 & 10 & $50.00 \%$ \\
\hline Skill2 & 3.17 & 10 & $31.67 \%$ \\
\hline Skill3 & 4.83 & 10 & $48.33 \%$ \\
\hline Skill4 & 2.75 & 10 & $27.50 \%$ \\
\hline Rating scale & $\mathbf{1 5 . 7 5}$ & $\mathbf{4 0}$ & $\mathbf{3 9 . 3 8 \%}$ \\
\hline
\end{tabular}

It can be seen from Table (2) that most of the percentages of professional skills related to textile arts are less than 50\%, and the percentage of the scale as a whole is (39.38\%), which indicates the weakness of these skills among the students of the research sample before using the overall quality standards.

Diagram (1) illustrates that:

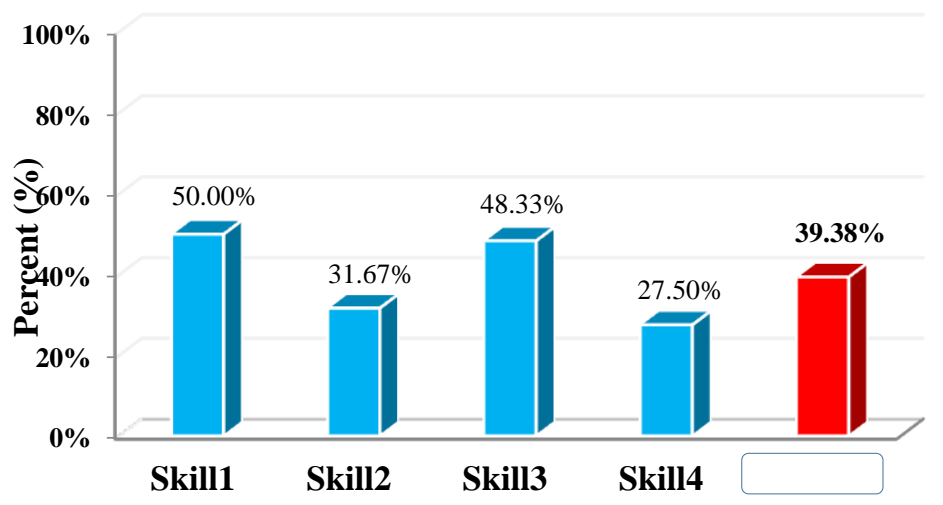

Figure (1): shows the percentages of the averages of the scores for the pre-application of skills and the scale as a whole.

From Table (2), its results, and Chart (1), the first sub-question has been answered.

The second sub-question:

The question states, "Are there statistically significant differences between the mean scores of the experimental group students in the pre and post applications of the objective achievement of assessing the knowledge contained in the program?"

To answer this question, the researcher used the "Wilcoxon Signed Ranks Test", and the results were as shown in Table (3): 


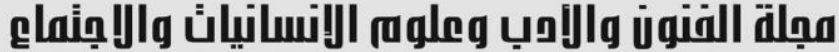 \\ Journal of Arts, Literature, Humanities and Social Sciences www.jalhss.com}

Volume (69) July 2021

يوليو 2021

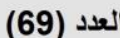

Table (3): the significance of the differences between the mean scores of the experimental group students in the pre and post applications of the objective achievement to assess the knowledge contained in the program

\begin{tabular}{|l|c|c|c|c|c|}
\hline Ranks & N & $\begin{array}{c}\text { Mean } \\
\text { Rank }\end{array}$ & $\begin{array}{c}\text { Sum of } \\
\text { Ranks }\end{array}$ & Z & P-value \\
\cline { 1 - 4 } Negative Ranks & 0 & 0 & 0 & & \\
\cline { 1 - 4 } Positive Ranks & 12 & 6.5 & 78 & \multirow{2}{*}{3.115} & \multirow{2}{*}{0.002} \\
\cline { 1 - 4 } Ties & 0 & & & \\
\cline { 1 - 5 } Total & $\mathbf{1 2}$ & & & & \\
\hline
\end{tabular}

Table (3) shows that there are statistically significant differences between the mean scores of the experimental group students in the pre and post applications of objective achievement for assessing the knowledge contained in the program, where the value of "Z" was (3.115) and the level of significance (0.002).

Diagram (2) illustrates that:

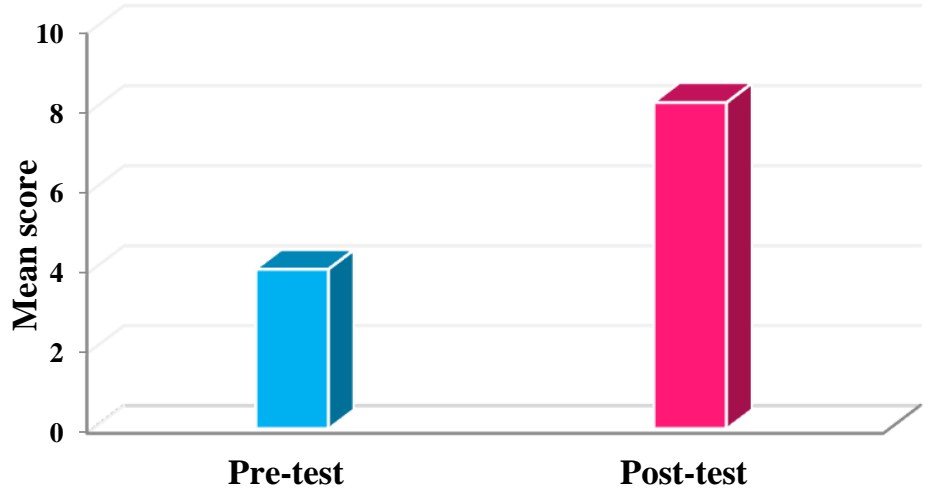

Figure (2): shows the mean scores of the experimental group students in the pre and post applications of objective achievement to assess the knowledge contained in the program.

From Table (3) and its results and graph (2), the second sub-question was answered, where there are statistically significant differences between the mean scores of the experimental group students in the pre and post applications of objective achievement to assess the knowledge contained in the program.

\section{The third sub-question:}

The question states, "Are there statistically significant differences between the mean scores of the experimental group students in the pre and post measurements of the level of professional skills related to textile arts?" 


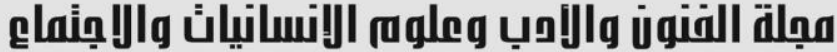 \\ Journal of Arts, Literature, Humanities and Social Sciences www.jalhss.com}

Volume (69) July 2021 العدد (69) يوليو 2021

Table (4): The significance of the differences between the mean scores of the experimental group students in the pre and post measurements of the level of professional skills related to textile arts.

\begin{tabular}{|c|c|c|c|c|c|c|}
\hline & Ranks & $\mathbf{N}$ & $\begin{array}{l}\text { Mean } \\
\text { Rank }\end{array}$ & $\begin{array}{l}\text { Sum of } \\
\text { Ranks }\end{array}$ & $\mathbf{Z}$ & P-value \\
\hline \multirow{4}{*}{$\begin{array}{c}\text { Skill1 } \\
\text { Post - Pre }\end{array}$} & Negative Ranks & 0 & 0 & 0 & \multirow{4}{*}{3.084} & \multirow{4}{*}{0.002} \\
\hline & Positive Ranks & 12 & 6.5 & 78 & & \\
\hline & Ties & 0 & & & & \\
\hline & Total & 12 & & & & \\
\hline \multirow{4}{*}{$\begin{array}{c}\text { Skill2 } \\
\text { Post - Pre }\end{array}$} & Negative Ranks & 0 & 0 & 0 & \multirow{4}{*}{3.097} & \multirow{4}{*}{0.002} \\
\hline & Positive Ranks & 12 & 6.5 & 78 & & \\
\hline & Ties & 0 & & & & \\
\hline & Total & 12 & & & & \\
\hline \multirow{4}{*}{$\begin{array}{c}\text { Skill3 } \\
\text { Post - Pre }\end{array}$} & Negative Ranks & 0 & 0 & 0 & \multirow{4}{*}{3.093} & \multirow{4}{*}{0.002} \\
\hline & Positive Ranks & 12 & 6.5 & 78 & & \\
\hline & Ties & 0 & & & & \\
\hline & Total & 12 & & & & \\
\hline \multirow{4}{*}{$\begin{array}{c}\text { Skill4 } \\
\text { Post - Pre }\end{array}$} & Negative Ranks & 0 & 0 & 0 & \multirow{4}{*}{3.082} & \multirow{4}{*}{0.002} \\
\hline & Positive Ranks & 12 & 6.5 & 78 & & \\
\hline & Ties & 0 & & & & \\
\hline & Total & 12 & & & & \\
\hline \multirow{4}{*}{$\begin{array}{l}\text { Rating scale } \\
\text { Post - Pre }\end{array}$} & Negative Ranks & $\mathbf{0}$ & $\mathbf{0}$ & $\mathbf{0}$ & \multirow{4}{*}{3.074} & \multirow{4}{*}{0.002} \\
\hline & Positive Ranks & 12 & 6.5 & 78 & & \\
\hline & Ties & $\mathbf{0}$ & & & & \\
\hline & Total & 12 & & & & \\
\hline
\end{tabular}

To answer this question, the researcher used the "Wilcoxon Signed Ranks Test", and the results were as shown in Table (4):

Table (4) shows that there are statistically significant differences between the mean scores of the experimental group students in the pre and post measurements of the levels of professional skills related to textile arts, where the "Z" values for skills ranged between (3.082 - 3.097), and reached (4.074) for the scale as a whole, all of which are indicative. Statistically at the significance level (0.002). 


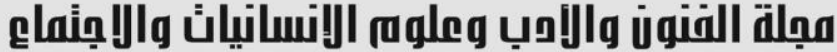 \\ Journal of Arts, Literature, Humanities and Social Sciences www.jalhss.com}

Volume (69) July 2021

يوليو 2021

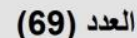

Figures (3) and (4) illustrate this:

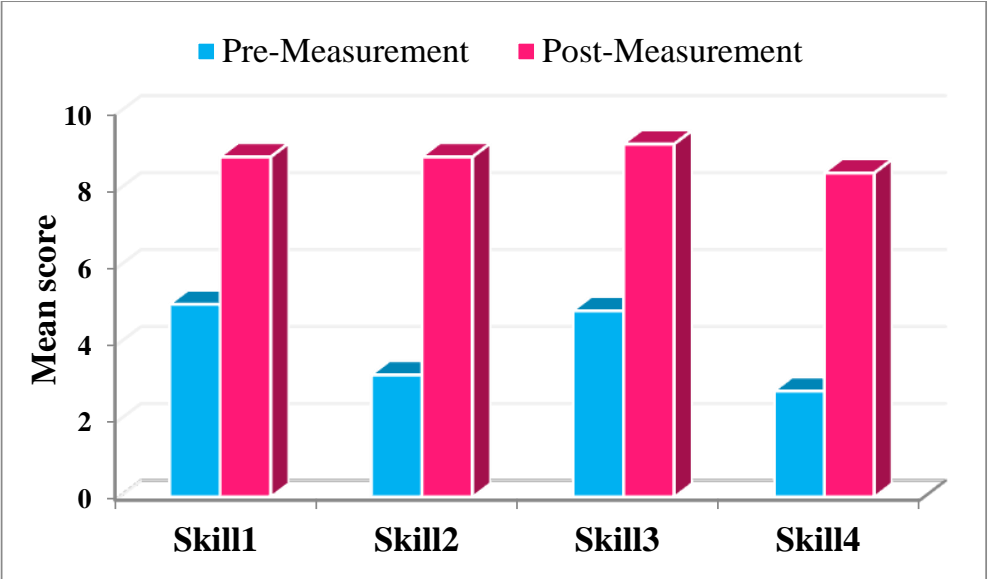

Figure (3): shows the mean scores of the experimental group students in the pre and post measurements of the levels of professional skills related to textile arts.

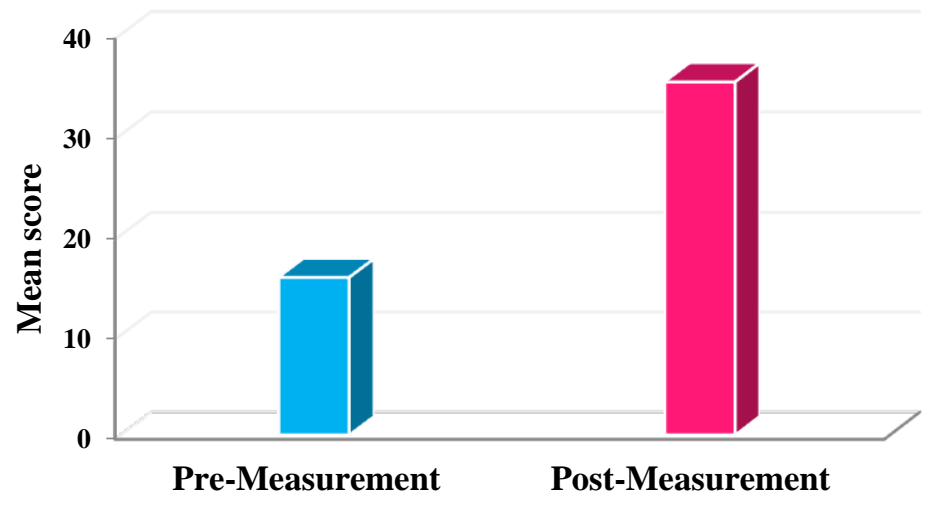

Figure (4): shows the mean scores of the experimental group students in the pre and post measurements of the scale as a whole.

From Table (4) and its results, and Figures (3) and (4), the third sub-question was answered, where there are statistically significant differences between the mean scores of the experimental group students in the pre and post measurements of the level of professional skills related to textile arts.

The fourth sub-question:

The question states "Is there an effect of quality standards?"

To answer this question, the researcher used the "Friedman Test", and the results came as shown in Table (5): 


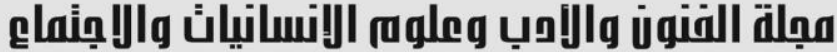 \\ Journal of Arts, Literature, Humanities and Social Sciences www.jalhss.com}

Volume (69) July 2021

العدد (69) يوليو 2021

Table (5): The significance of the differences between the averages of the number of errors and the mean completion time in minutes for the experimental group students in the note card.

\begin{tabular}{|c|c|c|c|c|c|c|c|}
\hline \multicolumn{2}{|c|}{ Pointer } & Repeat. & Mean Rank & $\mathbf{N}$ & Chi-Square & df & P-value \\
\hline \multirow{3}{*}{ Error } & Error1 & 4 & 3.00 & 12 & \multirow{3}{*}{23.532} & \multirow{3}{*}{2} & \multirow{3}{*}{0.001} \\
\hline & Error2 & 8 & 1.96 & 12 & & & \\
\hline & Error3 & 16 & 1.04 & 12 & & & \\
\hline \multirow{3}{*}{ Time } & Time1 & 4 & 2.88 & 12 & \multirow{3}{*}{18.878} & \multirow{3}{*}{2} & \multirow{3}{*}{0.001} \\
\hline & Time2 & 8 & 1.88 & 12 & & & \\
\hline & Time3 & 16 & 1.25 & 12 & & & \\
\hline
\end{tabular}

Table (5) shows the existence of statistically significant differences with respect to the error index, where the value of "Chi-Square" was $(23,532)$ and the level of significance (0.001). Also, it was found that there were statistically significant differences with respect to the indicator of completion time in minutes, where the value of "Chi-Square" was (0.001). (18.878) and the significance level (0.001).

Figures (5) and (6) illustrate this

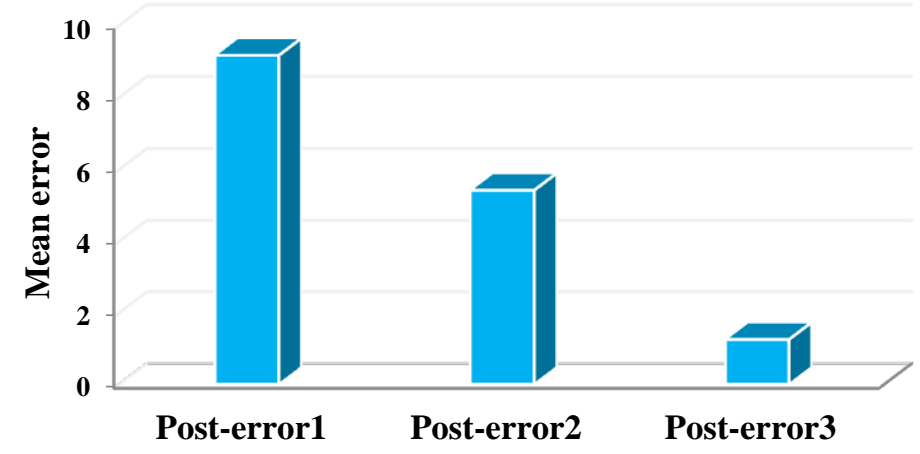

Figure (5): shows averages of errors according to the stages. 


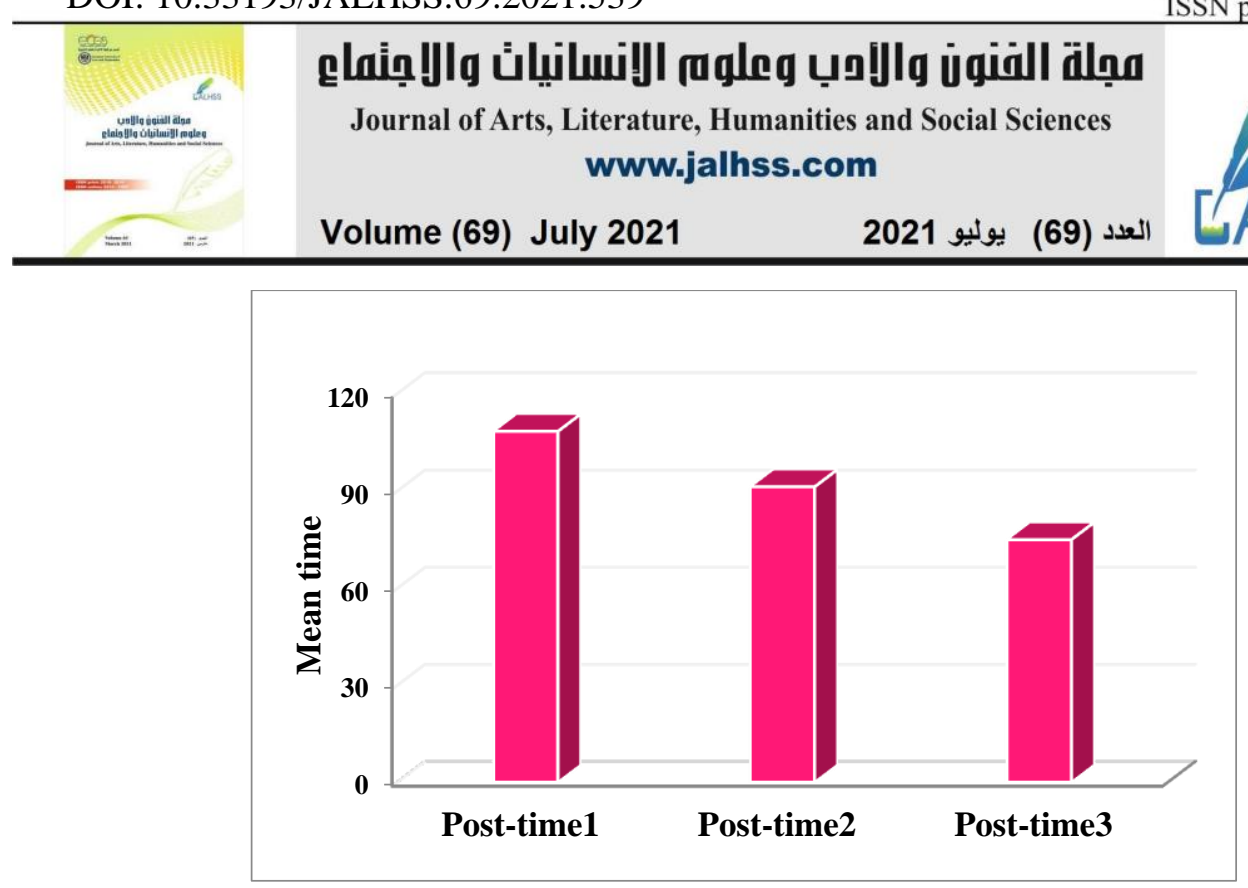

Figure (6): shows the average completion time in minutes according to the stages.

From Table (5) and its results, and Figures (5) and (6), the fourth subquestion has been answered, where there is an effect of quality standards.

\section{The fifth sub-question:}

The question states, "Is there a relationship between product quality and the opening of new fields of work in textile fields?"

To answer this question, the researcher used the Linear Regression test, and the results were as shown in Table (6):

Table (6): Results of regression analysis of the relationship between professional

skills related to textile arts (independent variable) and product quality (dependent variable).

\begin{tabular}{|c|c|c|c|c|c|c|c|c|}
\hline Pointer & & $\begin{array}{l}\text { Sum of } \\
\text { Squares }\end{array}$ & df & Mean Square & $\mathbf{F}$ & P-value & $\mathbf{R}$ & $\mathbf{R}^{2}$ \\
\hline \multirow{3}{*}{ Error } & Regression & 6.82 & 1 & 6.82 & \multirow{3}{*}{19.87} & \multirow{3}{*}{0.001} & \multirow{3}{*}{-0.816} & \multirow{3}{*}{0.665} \\
\hline & Residual & 3.43 & 10 & 0.34 & & & & \\
\hline & Total & 10.25 & 11 & & & & & \\
\hline \multirow{3}{*}{ Time } & Regression & 1344.44 & 1 & 1344.44 & \multirow{3}{*}{14.85} & \multirow{3}{*}{0.003} & \multirow{3}{*}{-0.773} & \multirow{3}{*}{0.598} \\
\hline & Residual & 905.56 & 10 & 90.56 & & & & \\
\hline & Total & 2250.00 & 11 & & & & & \\
\hline
\end{tabular}

Table (6) shows that there is a negative correlation between the professional skills related to textile arts (independent variable) and the quality of the product (dependent variable) according to the error index and the completion time index in minutes, where the correlation coefficient reached $(-0.816$, 0.773). $\mathrm{P} "(19.87,14.85)$ and the level of significance reached $(0.001,0.003)$, respectively, which indicates the semantics of the correlation model and the 


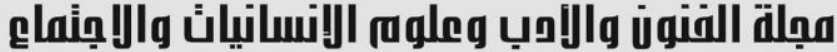 \\ Journal of Arts, Literature, Humanities and Social Sciences www.jalhss.com}

Volume (69) July 2021

يوليو 2021

(69) (6عدد)

possibility of using it for mathematical prediction. Table (7) shows the regression coefficients for the risk index and the time of completion index.

Table (7): shows the regression coefficients for the hazard index, completion time index, and their significance.

\begin{tabular}{|c|c|c|c|c|c|}
\hline \multirow{2}{*}{ Pointer } & & B & Beta & t & P-value \\
\hline \multirow{2}{*}{ Error } & (Constant) & 21.704 & & 4.726 & 0.001 \\
\cline { 2 - 6 } & Rating scale & -0.580 & -0.816 & -4.457 & 0.001 \\
\hline \multirow{2}{*}{ Time } & (Constant) & 362.222 & & 4.856 & 0.001 \\
\cline { 2 - 6 } & Rating scale & -8.148 & -0.773 & -3.853 & 0.003 \\
\hline
\end{tabular}

Table (6) shows the significance of the regression coefficients, reaching (-0.580) for the error index and (-8.148) for the completion time index in minutes.

Figures (7) and (8) illustrate this:

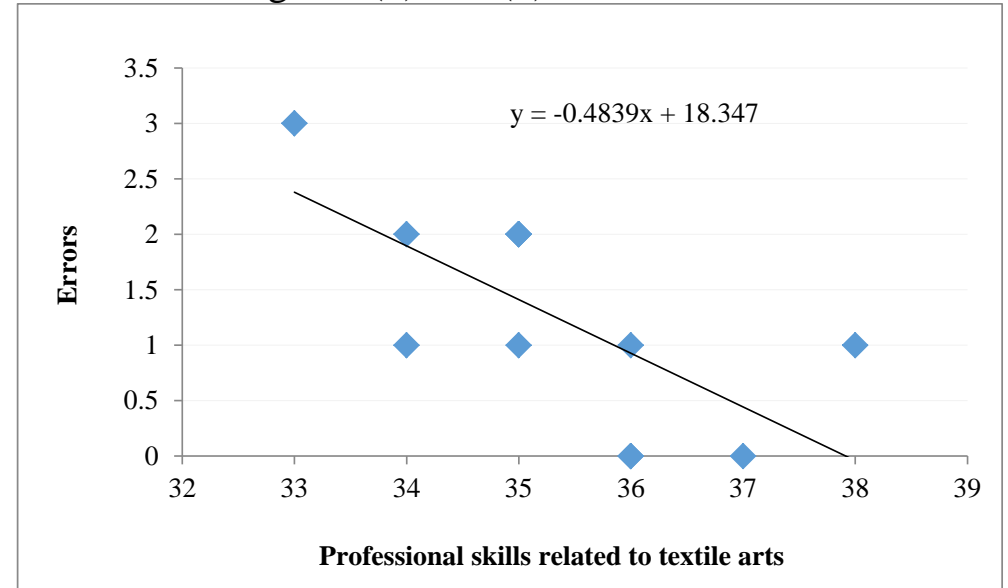

Figure (7): shows the relationship between professional skills related to textile arts (independent variable) and errors (dependent variable).

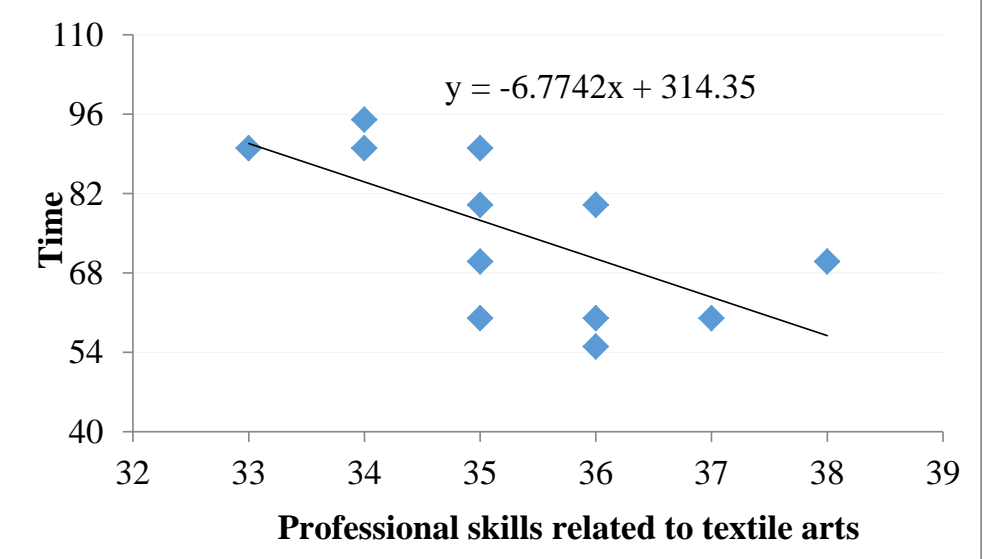

Figure (8): shows the relationship between the professional skills related to textile arts (independent variable) and the time of completion in minutes (dependent variable). 


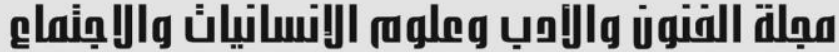 \\ Journal of Arts, Literature, Humanities and Social Sciences www.jalhss.com}

Volume (69) July 2021

يوليو 2021

(69) (69) (العدد)

From tables (6) and (7) and their results, as well as graphs (7) and (8), the fifth sub-question has been answered, where there is a relationship between product quality and the opening of new fields of work in textile fields.

\section{The main question:}

The question states, "What is the effect of using comprehensive quality standards on developing creativity and innovation skills related to textile arts for female students at Najran University?"

To answer this question, the researcher used the effect size equation, and Cohen gave an explanation of the size of the effect as it is small if its value is (0.1), medium if its value is (0.3), and large if its value is (0.5), and the results are as shown. In Table (8):

Table (8): The effect of using comprehensive quality standards on developing creativity and innovation skills related to textile arts for female students at Najran University.

\begin{tabular}{|l|c|c|c|}
\hline Test & $\mathbf{N}$ & Z / Chi-square & Effect size \\
\hline Objective achievement & 12 & 3.115 & 0.90 \\
\hline Rating scale & 12 & 3.074 & 0.89 \\
\hline Error & 12 & 23.532 & 0.98 \\
\hline Time & 12 & 18.878 & 0.79 \\
\hline
\end{tabular}

Table (8) shows the effect size values for using comprehensive quality standards in developing creativity and innovation skills related to textile arts for female students at Najran University. It indicates that the effect of using comprehensive quality standards was significant and led to the development of creativity and innovation skills related to textile arts for Najran University students.

From the tables (8) and their results, the main question was answered, as the use of comprehensive quality standards led to the development of creativity and innovation skills related to textile arts for female students of Najran University.

\section{Recommendations:}

- The need to continue training programs to qualify the community to set up small projects to face unemployment and find a field in the labor market 


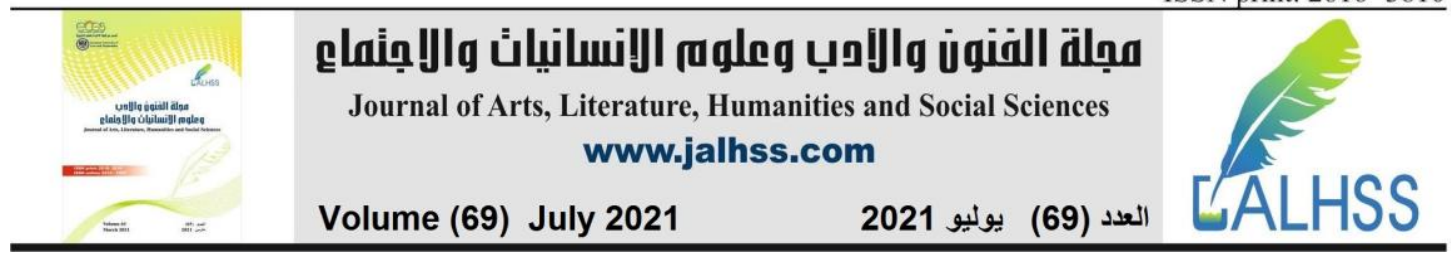

- Quality and its concept are used in all levels of life because of its impact on the building of the individual and its development for competition and excellence, to make quality part of his life for creativity and problem solving

- The importance of having a standard reference in the field of textile that can be referenced in the processes of development and improvement through the reference feeding on which control, control and treatment of deficiencies.

\section{References}

1. Abu Al-Anin, J. (2000). Utilizing the true incremental pattern to achieve a balance between the aesthetic values and functional performance of female scarf fabrics by using elements of Islamic plant decoration. Journal of Sciences and Arts, 3(17), 196-201

2. Adawiya, A. (2018). The effectiveness of an educational program for some simple tissue structures using multimedia. Journal of Specific Education, 7(17), 161-195.

3. Al-Adawi, M. (2005). Application of total quality management in the study of textile design and printing. A paper presented to the Twelfth Annual National Conference "Developing the Performance of Arab Universities in the Light of Comprehensive Quality Standards", Ain Shams University, Egypt.

4. Al-Adwani, K. (2020). A proposed training program to develop the concepts of comprehensive quality and its applications in education for quality specialists and school principals in the Republic of Yemen in light of sustainable development College of Education. A paper presented to the Second Scientific Conference of Administrative Sciences "Sustainable Development a Pillar of Security، Stability and Safety", University of Sanaa, Yemen.

5. Al-Amiri, A. (2020). Obstacles to the application of comprehensive quality management and ways to improve it from the viewpoint of the students of the History Department at the College of Education for Girls at the University of Baghdad. Al-Fatih Journal (81), 27-55.

6. Alex, B. (2004). Training and qualifying program for workers

7. in Nike Company in Europe. Netherlands: Nike.

8. Al-Ghamdi, A. (2017). The effectiveness of e-learning as a creative introduction to teaching hand weaving. Education Through Art, 3(11), 1-27.

9. Al-Rabiah, O. (2020). The degree of application of comprehensive quality management standards in Jordanian private universities from the viewpoint of faculty members. Journal for Educational Sciences, 4(44), 157176.

10. Al-Saleh, M. (2010). Producing textiles with aesthetic and functional values using some structural elements (Ph.D. dissertation). Princess Nourah bint Abdulrahman University, Saudi Arabia. 


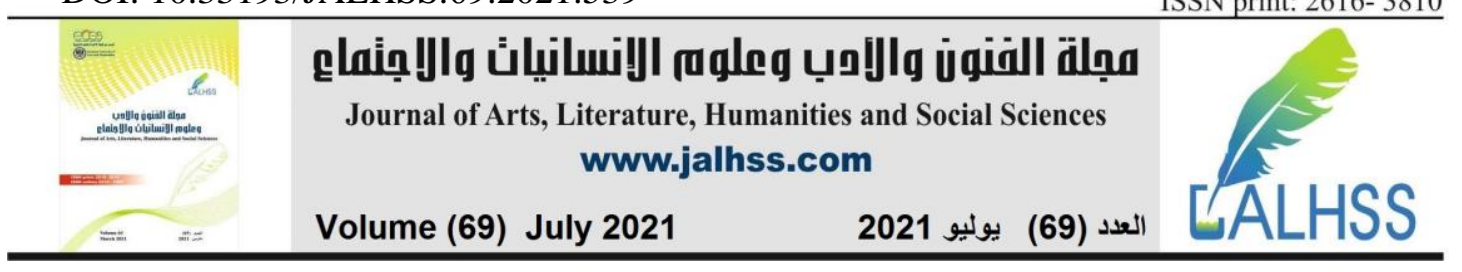

11. Al-Shimi, M. (2012). Creation of decorative designs based on simple textile compositions to enrich the subjects of design and weaving for art education students. Journal of the Faculty of Specific Education- Mansoura University, (23), 1230-1252.

12. El-Yazal, M., Ibrahim, H., \& Abdelqawy, A. (2014). A proposed program based on the environmental approach to the development of creativity. Educational Sciences, 22 (3), 641-661.

13. Hassan, R. (2010). Plastic artifacts of textile surface tactics. A paper presented to the Fifth Annual Arab Scientific Conferencer Faculty of Education, Mansoura University, Egypt.

14. Ibn Aishi, A. (2018). Diagnosing the reality of applying some principles of comprehensive quality management in Algerian industrial enterprises. Review of Advanced Economic Studies, 3(1), 1-22.

15. Ibrahim, N., Al-Jamal, M., \& Zalat, A. (2020). Studying the effect of different textile structures on some functional performance properties of upholstery fabrics. Journal of Specific Education Research, 18(60), 555-589.

16. Mabrouk, H. (2007). Quality standards and production of some textile products used in surgical rooms (Master's thesis). Helwan University, Egypt.

17. Jenkins, D. (2003). The Cambridge history of western textile. UK: Cambridge University.

18. Levi Strauss Company. (2006). The effect of program organization for sales managers training on sale value. UK: Levi Strauss Company.

19. Mahmoud, S. (2003). A study of modern artistic trends in employing the decorative unit as an input to teaching design using computers (Ph.D. dissertation). Ain Shams University, Egypt.

20. Mahmoud, A. (2013). Using ready-made tapes to overcome the problems of implementing textural compositions for junior students. Journal of Mansoura University, (31), 284-292.

21. Metwally, M. (2002). Applying one of the quality methods to the textile industry. Journal of Sciences and Arts- Helwan University, 2 (12), 72-79.

22. Muhammad, A. (2000). An analytical study of the importance of quality in the textile and knitting industry and its use in international marketing. Journal of Sciences and Arts-Helwan University, 12(3), 69-73

23. Naji, S. (2012). Designs of gentle textile fabrics and the data of color influences in them. Babel University Journal (Human Sciences), 2 (20), 161-174.

24. Niyaz, S. (2008). The effectiveness of using a training program to develop some language communication skills for preschoolers in autistic children in Jeddah governorate (Master's thesis). Taibah University, Saudi Arabia.

25. Raj, C. Augello, M. \& Dent, A. (2007). Harnessing the world wide web in eye emergency education and training. Journal of Emergency Primary Health Care, 5(4), $1-2$.

26. Saqr, A. (2003). A teaching unit based on the combination of new techniques for tangible values and their influence in the construction of decorative painting (Ph.D. Dissertation). Ain Shams University, Egypt. 


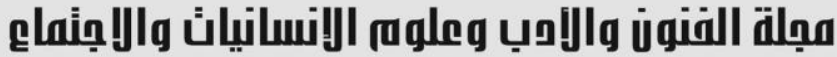 \\ Journal of Arts, Literature, Humanities and Social Sciences www.jalhss.com}

Volume (69) July 2021

يوليو 2021

(69) (69)

27. Saleh, I. (2011). Conceptual proposal for a training program to develop some skills in educational technology for teacher trainers in the basic education stage in the Sultanate of Oman. Educational Technology, 1-74.

28. Siddiq, K. (2012). The use of the international quality system in designing a program to improve performance rates within the Egyptian textile facility (Ph.D. dissertation). Helwan University, Egypt.

29. Taha, H. \& Alshemy, M. (2020). An integrative plastic vision between design and textile materials as an entrance to building three-dimensional artworks (experimental study). Journal of Mansoura University, (44), 389-413.

30. Uywn, V. (2003). Textile firms co-operate to weave training. Retrieved from https://www.hrreporter.com/news/hr-news/textile-firms-co-operate-to-weavetraining/309551.

31. Yen- Pablo, B. \& Brian, K. (2000). How do textile companies keep quality high?. Management Research News, 23(7/8), 128-131.

32. Yunus, S. (2014). The art of light as one of the modern artistic

33. trends and its effect on textile crafts. Cairo University-Journal of Specific Education, 4(14), 161-195.

34. Yusuf, P. (2012). A contemporary vision to study the art of hand weaving in Saudi universities. Helwan University Journal of Science and Arts Mag, 4 (24), 6175. 